\title{
AFRICA IN INTERNATIONAL HUMAN RIGHTS TEXTBOOKS
}

\section{CHRISTOF HEYNS* AND MAGNUS KILLANDER ${ }^{\dagger}$}

It is encouraging to see that the African regional human rights system is receiving increased consideration in textbooks about international human rights and, as such, that the African experience is becoming more integrated into the global understanding of what the concept of human rights entails. This note examines the way in which this subject is treated by a selection of textbooks aimed at students of international human rights that are currently being widely used. We highlight instances of discrepancies between the system's presentation and its actual operation.

The African regional human rights system is the youngest of the three regional human rights systems. The main African human rights instrument is the African Charter on Human and Peoples’ Rights (African Charter) ${ }^{1}$, ratified by all 53 member states of the African Union (AU). ${ }^{2}$ The African Commission on Human and Peoples’ Rights (African Commission) was established in 1987 after

\footnotetext{
* Professor of Human Rights Law and Director, Centre for Human Rights, University of Pretoria, South Africa.

${ }^{\dagger}$ Researcher, Centre for Human Rights, University of Pretoria, South Africa.

${ }^{1}$ African Charter on Human and Peoples’ Rights, 26 June 1981, OAU Doc. CAB/LEG/67/3 rev. 5 (entered into force 21 October 1986), reprinted in 21 ILM 59 (1982) and in C. Heyns (ed) Human Rights Law in Africa (2004) 134.

${ }^{2}$ Constitutive Act of the African Union, 11 July 2000, OAU Doc. CAB/LEG/23.15 (entered into force 26 May 2001), reprinted in Heyns, supra note 1, 181. The AU was launched in July 2002, replacing the Organisation for African Unity (OAU) as the regional cooperation organisation encompassing all African countries except Morocco. The AU Constitutive Act sets out the protection of human rights as one of the purposes of the AU.
} 
the entry into force of the African Charter. The Commission monitors state compliance with the Charter mainly through state reports and complaints procedures.

A protocol to the Charter establishing an African human rights court was adopted in 1998 and entered into force in 2004. ${ }^{3}$ Judges were appointed in January 2006, but the Court has not yet been established. A protocol to the Charter dealing with the rights of women entered into force in $2005{ }^{4}$ The African human rights system also includes the African Charter on the Rights and the Welfare of the Child ${ }^{5}$, which entered into force in 1999, and a committee to monitor its implementation. Various other AU organs play a role in promoting and protecting human rights.

For those interested in the African system, an increasing body of information is available, consisting of primary sources and commentary by scholars specialising in the field of human rights in Africa. Decisions of the African Commission on individual communications are available on the internet and in law reports. ${ }^{6}$ Resolutions adopted by the Commission and other primary sources of the

\footnotetext{
${ }^{3}$ Protocol to the African Charter on Human and Peoples' Rights on the establishment of an African Court on Human and Peoples' Rights, 9 June 1998, OAU Doc. CAB/LEG/66.5 (entered into force 25 January 2004), reprinted in Heyns, supra note 1, 170.

${ }^{4}$ Protocol to the African Charter on Human and Peoples' Rights on the Rights of Women in Africa, 11 July 2003 (entered into force 25 November 2005), reprinted in C. Heyns Compendium of key human rights documents of the African Union (2005) 38.

${ }^{5}$ African Charter on the Rights and Welfare of the Child, 11 July 1990, OAU Doc. CAB/LEG/24.9/49 (entered into force 29 November 1999) reprinted in Heyns, supra note 1, 143.

${ }^{6}$ The Activity Reports of the African Commission are available on its web site <www.achpr.org>. See also <www.chr.up.ac.za>. The decisions of the African Commission on individual communications are also published in the African Human Rights Law Reports (AHRLR) and the International Human Rights Reports. References to decisions by the African Commission in this note is to AHRLR, published by Juta, Cape Town, and also available at <www.chr.up.ac.za>
} 
Commission and its parent organisation, the African Union, are also available on the internet and in reference guides. ${ }^{7}$ A number of books covering the system in detail have been published. ${ }^{8}$ Articles dealing with human rights law in Africa appear with increasing frequency in international journals. A small number of specialised journals in the field are also published. ${ }^{9}$

While it may have been understandable in the past that the African system received scant treatment in human rights literature, no justification exists anymore and indeed, writers of textbooks on international human rights law have started to integrate commentary on the African system into their work. In contrast with earlier practice, a number of contemporary textbooks on international human rights law include full coverage of the African system. This is significant, viewed in the light of the fact that the universality of human rights does not simply imply that the same set of norms apply to everyone everywhere; it also entails that those norms draw on and reflect global values and experiences. Should it fail to take account of the African experience, the emerging international human rights system will be incomplete, throwing into question the use of the word "international”, as one seventh of the world's population will have been ignored. Moreover, as is the case with any region, Africa cannot be expected to be held accountable in terms of standards which it does not help to define. Human rights is not about one part of humanity being held accountable to another part, but about humanity measuring itself against its own higher values.

\footnotetext{
${ }^{7}$ R. Murray \& M. Evans (eds.) Documents of the African Commission on Human and Peoples' Rights (2001) and Heyns, supra note 1.

${ }^{8}$ See e.g. M. Evans \& R. Murray (eds.) The African Charter on Human and People’s rights - The system in practice 1986-2000 (2002), F. Ouguergouz The African Charter on Human and Peoples' Rights: A comprehensive agenda for human rights (2003).

${ }^{9}$ E.g. the African Human Rights Law Journal published by Juta, Cape Town.
} 
The existence of a regional human rights system in Africa therefore provides the continent with an entry point into international human rights law and the other way around. On the one hand, this allows the people of the continent to make a stronger contribution towards the development of international human rights law. On the other hand, to the extent that the African experience is integrated into the global system, one may expect a greater acceptance of these norms by African states and citizens.

The increased focus on human rights standards in Africa may ensure that these standards are taken more seriously by those in Africa and abroad. For example, the fact that the African system has been covered in the different editions of Thomas Buergenthal's International human rights in a nutshell on a par with the Inter-American and European systems has helped to emphasise the importance of this system to generations of young human rights practitioners from around the world.

While there are indications of increased integration of Africa into the world literature on human rights, concerns about continued neglect remains valid. ${ }^{10}$ In addition to issues of frequency of references or quantity, however, it is important also to emphasize the question concerning the quality of the references to the African system in those publications in which it is included.

The way in which six recent and widely used publications on international human rights present the African human rights system will now be investigated. First the scope of the coverage: International human rights in a nutshell by Buergenthal, Shelton and Stewart devotes a chapter to the “African system of human and peoples' rights”. ${ }^{11}$ Jack Donnelly’s Universal human rights in

\footnotetext{
${ }^{10}$ See R. Murray, International human rights: Neglect of perspectives from African institutions, 55 ICLQ 193 (2006).

${ }^{11}$ T. Buergenthal, D. Shelton, D.P. Stewart International human rights in a nutshell ( $3^{\text {rd }}$ ed., 2002)
} 
theory \& practice ${ }^{12}$ contains a chapter on "International human rights regimes" which includes one page on Africa, included under the heading “Africa, Asia, and the Middle East”; Manfred Nowak’s Introduction to the international human rights regime ${ }^{13}$ contains a chapter entitled "Organization of African Unity (OAU) / African Union (AU)”; and Rhona KM Smith’s Textbook on international human rights ${ }^{14}$ includes a chapter on “The African Union”. Javaid Rehman's International human rights law - a practical approach ${ }^{15}$ has a narrower focus and includes a chapter entitled "African Charter on Human and Peoples’ Rights”. Christian Tomuschat's book Human rights - Between idealism and realism ${ }^{16}$ is arranged differently to include chapters dealing with state reporting, complaints procedures, etc. It examines the global and regional systems under each of these headings.

Donnelly, Rehman and Tomuschat do not mention the fact that the AU has replaced the OAU, despite the fact that the AU Constitutive Act, with its increased focus on human rights, was adopted already in 2000 and entered into force in 2001. In setting out the organs of the AU, Buergenthal leaves out the Pan-African Parliament and the Economic, Social and Cultural Council, both with important human rights mandates. None of the authors mention the African Peer Review Mechanism (APRM), a mechanism with a human rights mandate established by the AU in 2002 .

\footnotetext{
${ }^{12}$ J. Donnelly Universal human rights in theory \& practice $\left(2^{\text {nd }}\right.$ ed., 2003).

${ }^{13}$ M. Nowak Introduction to the international human rights regime (2003).

${ }^{14}$ R.K.M. Smith Textbook in international human rights $\left(2^{\text {nd }}\right.$ ed., 2005).

${ }^{15} \mathrm{~J}$. Rehman International human rights law - a practical approach (2002).

${ }^{16}$ C. Tomuschat Human rights - between idealism and realism (2003).
} 
As mentioned above, the African Charter was ratified by all the $53 \mathrm{AU}$ member states, the last being Eritrea in January 1999. Tomuschat refers to 51 states parties ${ }^{17}$ while Rehman simply states that "[a]ll states parties to the OAU are eligible to become parties to the Charter". ${ }^{18}$

Donnelly states that “[1]ittle of substance seems to have emerged from [the African Commission's] proceedings". ${ }^{19}$ It is not clear to what this broad observation refers, but it has the potential to leave the reader with the erroneous impression that the Commission has not developed a significant jurisprudence.

Nowak's Introduction to the international human rights regime is one of the most useful texts in the field. However, the discussion of the African Charter has some gaps. Nowak states that the individual complaints procedure of the African Charter "seems more like the 1503 procedure before the UN Human Rights Commission ... than a treaty monitoring procedure' and states that the African Commission cannot consider 'isolated individual cases, no matter how serious”, and can only consider "a systematic pattern of gross human rights violations”. ${ }^{20}$

The view that the Commission can only respond to serious or massive violations of human rights was also followed by Buergenthal who in earlier editions of his work compared the African system with the 1503 procedure, stating that the "individual complaints mechanism of the Charter bears a striking resemblance to the procedure established by the UN under ECOSOC Resolution $1503 \ldots$... It differs very significantly from the individual petition system of the European and American

\footnotetext{
${ }^{17}$ Id., 140.

${ }^{18}$ Rehman, supra note 15, 237.

${ }^{19}$ Donnelly, supra note 12, 144.

${ }^{20}$ Nowak, supra note 13, 208.
} 
Conventions."21 A literal reading of article 58 of the African Charter may indeed give support for the interpretation that the Commission is only able to consider "serious and massive violations". Article 58 provides as follows:

1. When after deliberations of the Commission it appears that one or more communications apparently relate to special cases which reveal the existence of a series of serious or massive violations of human and peoples' rights, the Commission shall draw the attention of the Assembly of Heads of State and Government to these special cases.

2. The Assembly of Heads of State and Government may then request the Commission to undertake an in-depth study of these cases and make a factual report, accompanied by its findings and recommendations.

3. A case of emergency duly noticed by the Commission shall be submitted by the latter to the Chairman of the Assembly of Heads of State and Government who may request an indepth study.

Just looking at the text article 58 may conceivably be interpreted as describing a stage through which all individual complaints need to go (as interpreted by Nowak and others), but Commission practice from the start has been to see the article 58 procedure as a special procedure which should be followed only in respect of cases which the Commission wants to identify as "serious and massive violations” of human rights, and should not be followed in other cases.

Since it was established in 1987, the Commission has considered individual cases which do not reveal a pattern of serious or massive violations, deciding its first case in $1988 .^{22}$ Responding

\footnotetext{
${ }^{21}$ See e.g. T. Buergenthal International human rights in a nutshell ( $2^{\text {nd }}$ ed., 1995), 244-245.
} 
directly to the perception that the Commission cannot hear individual cases which do not reveal a pattern of systemic violations, the Commission stated as follows in the case of Jawara $v$ The Gambia:

41. ... The state also claims that the Commission is allowed under the Charter to take action only on cases which reveal a series of serious or massive violations of human rights.

42. This is an erroneous proposition. Apart from articles 47 and 49 of the Charter, which empower the Commission to consider interstate complaints, article 55 of the Charter provides for the consideration of 'Communications other than those of state parties'. Further to this, article 56 of the Charter stipulates the conditions for consideration of such communications (see also chapter XVII of the Rules of Procedure entitled 'Procedure for the Consideration of the Communications Received in Conformity with article 55 of the Charter'). In any event, the practice of the Commission has been to consider communications even if they do not reveal a series of serious or massive violations. It is out of such useful exercise that the Commission has, over the years, been able to built up its case law and jurisprudence. ${ }^{23}$

In the latest edition of the Nutshell, Buergenthal has now incorporated Commission practice into his portrayal of the Charter, and comments as follows:

The individual communications mechanism set forth in the Charter bears a string resemblance to the relatively limited procedure established by the UN under ECOSOC Resolution 1503 ... As interpreted and applied by the Commission, however, it has increasingly come to

\footnotetext{
${ }^{22}$ Korvah v Liberia (2000) AHRLR 140 (ACHPR 1988).

${ }^{23}$ Jawara v The Gambia (2000) AHRLR 107 (ACHPR 2000), paras 41 and 42.
} 
approximate the much more liberal individual petition systems of the European and American Conventions. $^{24}$

Turning to the substantive provisions of the Charter, many commentators have interpreted and portrayed what have been called the "claw-back" clauses of the Charter in a way which does not reflect Commission practice. "Claw-back” clauses are provisions which seem to grant rights with one hand while taking them away with the other. This occurs where the Charter recognises a specific right but in the same clause gives the state a seemingly unqualified right to use domestic law to limit this right. According to article 9(2) of the African Charter, for example, "Every individual shall have the right to express and disseminate his opinions within the law.” In this example the provision “... within the law” constitutes a so-called claw-back clause. At first glance there is nothing that prevents domestic law from limiting or even eliminating this right, leaving the Commission without a meaningful supervisory role and the victim of a violation without recourse.

The Commission, to its credit, has repeatedly held that in such cases the domestic law used to limit the right in question must comply with international standards. ${ }^{25}$ However, commentators frequently do not reflect this in their writings on the Charter and the impression is created that governments can rely on these claw-back clauses to justify national law that violates human rights.

\footnotetext{
${ }^{24}$ Buergenthal et al, supra note 11, 300-301.

${ }^{25}$ See e.g. Constitutional Rights Project and Others v Nigeria (2000) AHRLR 227 (ACHPR 1999), paras 14, 39, 40; Malawi African Association and Others v Mauritania (2000) AHRLR 149 (ACHPR 2000); and Media Rights Agenda v Nigeria (2000) AHRLR 262 (ACHPR 2000).
} 
Rehman, for example, states that in articles containing claw-back clauses "the state is permitted to justify limitations on the rights by reference to its own domestic laws”. ${ }^{26}$

An inflated perception of states' powers to restrict rights can be created by such a portrayal of the African Charter, leading to human rights violations. The reality of this danger is reflected in arguments before the Commission. For example, in Constitutional Rights Project and Others $v$ Nigeria, the Commission stated as follows: 'With specific regard to article 9, the government argued that "within the law" must refer to the current law of Nigeria, not to the Nigerian Constitution or an international standard' ${ }^{27}$

The issues raised above concerning the Commission's ability to consider individual communications and the claw-back clauses illustrate one of the problems confronting the AU human rights protection system. In a number of instances the wording of the African Charter is wide open to interpretation or contains clear gaps. It is not altogether surprising that authors become confused at times. To its credit the Commission has in a number of instances through creative interpretation given the Charter an interpretation that provides a higher level of protection to human rights than may appear from its literal reading, but due notice is not taken of the Commission's work. $^{28}$

\footnotetext{
${ }^{26}$ Rehman, supra note 15, 239. This view is followed, with reference to Rehman, by Eric Neumayer, Does international human rights treaties improve respect for human rights?, 49 Journal of Conflict Resolution 939 (2005).

${ }^{27}$ Constitutional Rights Project and Others v Nigeria, supra note 25, para 14.

${ }^{28}$ It has been argued that in the interests of the rule of law, the words of the Charter should at some point be brought in line with their interpretation by bodies such as the Commission, presumably by means of an optional protocol to the African Charter. Until that happens, however, there is a particular duty on the writers of textbooks to incorporate the decisions of the Commission into their texts on the African Charter. See C.
} 
Buergenthal's overview of the Commission's case law is the most comprehensive of the chapters under review. ${ }^{29}$ In other instances it seems as if textbook authors did not have proper access to the jurisprudence of the African Commission. Rehman's overview of the African system relies on dated secondary sources. Nowhere in his chapter does Rehman mention any decision taken by the Commission after 1997. His presentation of the procedures of the Commission with regard to individual communications ${ }^{30}$ seems to rely almost entirely on an article published in $1998 .{ }^{31}$ Under the heading 'Analysing the substantive rights in the Charter ${ }^{\text {,32 }}$ Rehman mentions only one decision by the Commission, Courson v Zimbabwe, decided in 1994. This decision he uses as authority for the statement that '[s]ome of the African States have been criticised for allowing such practices as female circumcision or for criminalising adult homosexuality' ${ }^{33}$ In reality the complaint in Courson, dealing with the criminalisation of homosexuality in Zimbabwe, was withdrawn and never decided on its merits. ${ }^{34}$

In Nowak's only reference to the case law of the Commission he states that

Heyns ‘The African regional human rights system: In need of reform?’ 1 African Human Rights Law Journal 155 (2001).

${ }^{29}$ Buergenthal et al, supra note 11, 304-309.

${ }^{30}$ Rehman, supra note 15, 256-262.

${ }^{31}$ C.A. Odinkalu \& C. Christensen 'The African Commission on Human and Peoples' Rights: The development of its non-state communication procedures’ 20 Human Rights Quarterly 235 (1998). The article relies on unofficial versions of the early decisions of the Commission.

${ }^{32}$ Rehman, supra note 15, 239-248.

${ }^{33}$ Id., 243.

${ }^{34}$ Courson v Zimbabwe (2000) AHRLR 335 (ACHPR 1995). 
the Commission in recent years has increased its efforts to examine individual cases, to identify those that reveal the existence of a series of massive human right violations, and to draw the attention of the Assembly of Heads of State and Government to these systematic patterns, as in cases against Nigeria (Ogoni people case), Malawi, and the Democratic Republic of Congo (Zaire). ${ }^{35}$

The case that Nowak refers to as 'the Ogoni people case', namely, SERAC and Another v Nigeria ${ }^{36}$, is one of the more prominent decisions of the Commission in recent years interpreting socioeconomic and peoples' rights in the Charter. Which 'recent' cases from Malawi and DRC that Nowak refers to is unclear. The most recent cases to be decided on merit against either of these countries were decided in 1995.

Smith makes reference to only three cases decided by the Commission. She quotes Free Legal Assistance Group and Others $v$ Zaire ${ }^{37}$ as supporting the view that the "emphasis is ... on securing a friendly settlement in what is clearly not meant to be a judicial process." ${ }^{38}$ In truth, the Commission has found violations in almost 50 cases, including the case against Zaire mentioned by Smith, and only closed a handful of cases because a friendly settlement has been reached.

An overview in a textbook that serves as an introduction to international human rights law can naturally not cover all aspects of a system. In this respect references to other literature are important. Buergenthal, Rehman and Smith omit a number of important works and Smith’s list of references has not been updated in the first edition of her book. Nowak's bibliography covers most

\footnotetext{
${ }^{35}$ Nowak, supra note 13, 211.

${ }^{36}$ SERAC and Another v Nigeria (2001) AHRLR 60 (ACHPR 2001).

${ }^{37}$ (2000) AHRLR 74 (ACHPR 1995).

${ }^{38}$ Smith, supra note $14,141$.
} 
of the important literature and web sites. Donnelly and Tomuschat give only a few references, albeit to relevant literature.

The African human rights system has once been referred to as "a sad joke" ${ }^{9}$ It is clear that the authors of chapters in the books under review take the African experience more seriously and this is to be welcomed. It appears that one of the obstacles in their way is the inaccessibility of Commission decisions which often place Charter provisions in a different light. For many years the Commission has done little to address this situation, but now the texts are made more accessible. One way to ensure greater accuracy in the portrayal of the African system is for libraries in other parts of the world to make the sources on this jurisprudence accessible. An international human rights library cannot claim to be comprehensive if it does not contain the primary texts on human rights in Africa, just as the international human rights order cannot be complete without giving Africa its rightful place both in terms of the quantity and the quality of the coverage of the system.

\footnotetext{
${ }^{39}$ G. Robertson Crimes against humanity - the struggle for global justice (2002). Robertson's description of the African human rights system focuses on identifying the many problems that face the system, seemingly without taking note of the positive aspects of the work of the Commission. For example he criticises the “claw-back clauses” in the Charter without having consulted the Commission's jurisprudence. Robertson further refers to the Commission's sessions as "peripatetic" and "slapstick", without providing information to substantiate these serious claims. Id., 65-68.
} 